\title{
Clinical and epidemiological characteristics of young patients with Peyronie's disease: a retrospective study
}

This article was published in the following Dove Press journal:

Research and Reports in Urology

9 July 2015

Number of times this article has been viewed

\section{Gianni Paulis 1,7 \\ Giorgio Cavallini² \\ Davide Barletta ${ }^{3}$ \\ Paolo Turchi ${ }^{4}$ \\ Antonio Vitarelli ${ }^{5}$ \\ Andrea Fabiani ${ }^{6}$}

'Regina Apostolorum Hospital, Andrology Center, Rome, Italy; ${ }^{2}$ Andrological Section, Gynepro Medical Team, Bologna, Italy; ${ }^{3}$ Department of Urology, Andrology Center, San Matteo Hospital, Pavia, Italy; ${ }^{4}$ Azienda ASL 4 Prato Andrology Service, Prato, Italy; ${ }^{5}$ Department of Urology, University of Bari, Bari, Italy; ${ }^{6}$ Department of Surgery, Section of Urology and Andrology, ASUR Marche 9, Macerata, Italy; ${ }^{7}$ Castelfidardo Medical Team, Peyronie's Disease Care Center, Rome, Italy
Correspondence: Gianni Paulis Castelfidardo Medical Team (SMS), Via Castelfidardo, 34 - 00185 , Rome, Italy Email paulisg@libero.it
Abstract: The average age of men affected by Peyronie's disease (PD) is approximately 50-55 years, but cases have been reported even in adolescence. Several studies have already investigated the presence of PD in young men, and these studies reported a PD prevalence that varies between $1.5 \%$ and $10.8 \%$. Having noticed a greater number of young patients in our centers in recent years, we decided to carry out a retrospective study to evaluate the prevalence of PD in patients aged $<40$ years, as well as to investigate any possible difference in evolution based on the age of PD patients. We selected a sample of patients $(n=271)$ with a similar time of onset of disease. We then stratified all 271 patients into two groups: group A (age $<40$ years $[n=46]$ ) and group B (age $\geq 40$ years $[n=225]$ ). All 271 patients were evaluated for the following variables: penile plaque volume, degree of penile curvature, penile pain, and erectile function. Plaque volume was measured in $\mathrm{cm}^{3}$ by dynamic penile color Doppler sonography after administration of intracavernosal alprostadil $10 \mathrm{mcg}$. The number of younger patients was 46 , accounting for $16.9 \%$ of the whole sample. Our study showed more frequent appearance and greater progression of penile curvature in younger patients. The average angle of penile curvature and average score of penile pain intensity in the younger men were significantly higher than in patients aged $\geq 40$ years ( $P=0.025$ and $P=0.0001$, respectively). In the younger patients, not only was the pain more intense (visual analog scale [VAS] of 5.2 versus 3.8 ), but it was also more frequently present than in patients aged $\geq 40$ years $(78.2 \%$ versus $62.2 \%)(P=0.042)$. We may conclude that since PD in young patients has a more acute onset and a greater possibility of progression, it should be treated conservatively as soon as it is diagnosed.

Keywords: Peyronie, young men, prevalence, penile curvature

\section{Introduction}

Peyronie's disease (PD) is a chronic inflammatory disease that affects the tunica albuginea of the corpora cavernosa. It is characterized from the outset by an inflammatory zone (plaque) where there is excessive production of collagen by fibroblasts and myofibroblasts. ${ }^{1,2}$ Several studies have shown that the excess of collagen present in PD is associated with a production of proinflammatory cytokines, such as TGF- $\beta 1{ }^{3,4}$ As penile plaque progressively builds up, it causes a reduction in elasticity in the affected region, which can frequently result in morphological changes of the penis: simple depressions, penile curvature, "hourglass" shape, and shortening of the penis.

PD is often associated with pain and erectile dysfunction. When the disease progresses, it inevitably makes penetration difficult or impossible.

Although the exact etiology of PD has not been elucidated yet, trauma has generally been recognized as a fundamental pathogenetic mechanism. ${ }^{5-7}$ Trauma or repeated microtrauma to the erect penis in genetically predisposed patients would thus trigger the 
inflammatory mechanism that leads to the deposition of fibrin and progressive destruction of elastic fibers. ${ }^{8-10}$ However, a number of studies have found a genetic and immunological component in patients with PD. ${ }^{11,12}$ A recent study has shown highly statistically significant association between $\mathrm{PD}$ and autoimmune disorders (odds ratio $=4.90 ; P<0.01$ ). ${ }^{13}$

The frequent coexistence of PD and other diseases, such as Dupuytren's disease and Paget's disease, is known. ${ }^{14-16}$ A recent study has shown that WNT2 is a genetic locus involved in genetic predisposition for both Dupuytren's disease and PD. ${ }^{17}$

Contrary to general belief, PD is not at all uncommon, and its prevalence varies between $3.2 \%$ and $13 \%{ }^{18-20}$ The average age of men affected by this disease is approximately 50-55 years, but cases have been reported even in adolescence. ${ }^{21}$ In the literature, the presence of PD at a young age $(<40$ years) has already been studied. In this age group, studies reported a prevalence of $\mathrm{PD}$ that varies between $1.5 \%$ and $10.8 \%{ }^{22-25}$ Having noticed, in recent years, a greater number of young patients in our centers, we decided to carry out a retrospective study to evaluate the prevalence of affected patients aged $<40$ years. A further purpose of the study was to investigate a possible different evolution based on the age of PD patients.

\section{Materials and methods}

This study was conducted by analyzing 441 patients with PD who were seen and treated at our center during the period between January 1, 2011 and January 1, 2015. As we planned to take into consideration the presence of a possible difference in evolution (volume of plaque, change in curvature angle, etc) between the two age groups (patients $<40$ years and patients $\geq 40$ years), we selected a sample of 271 patients who had a similar time of onset of disease corresponding to 8 to 12 months $(271 / 441=61.4 \%)$. The ages of the patients ranged between 20 and 73 years, with a mean age of 51.6 years. After the first meeting, all 271 patients were evaluated for the following variables: penile plaque volume, degree of penile curvature, penile pain, and erectile function. Plaque volume was measured, in $\mathrm{cm}^{3}$, by dynamic penile color Doppler sonography after administration of intracavernosal alprostadil $10 \mathrm{mcg}$. To calculate the volume of the penile plaque, we measured its three dimensions and used an ellipsoid formula:

$$
\mathrm{V}=\text { length } \times \text { width } \times \text { thickness } \times 0: 52
$$

which is typically used in other urogenital diseases. ${ }^{26-28}$ Penile curvature was evaluated in the course of erection, with penile dynamic color-duplex Doppler ultrasonography and photography through the penis, according to the Kelami technique. ${ }^{29}$

Where present, the intensity of penile pain was measured by a numerical rating scale (visual analog scale [VAS] score), where 0 signified no pain and 10 signified the worst pain possible. ${ }^{30}$ Evaluation of erectile function was carried out by administering the International Index of Erectile Function (IIEF) questionnaire. ${ }^{31}$ We used the full questionnaire of 15 questions and evaluated the answers to questions 1-5 and 15 , specific to erectile function. We considered normal a score as 26-30 points; patients who had a total score of less than 26 points were therefore identified as suffering from erectile dysfunction. ${ }^{31}$

We then stratified all 271 patients into two age groups: group A (age $<40$ years $[\mathrm{n}=46]$ ) and group $B$ (age $\geq 40$ years [225]).

This study was conducted in compliance with the Helsinki Declaration of 1975, according to its fourth revision in 2000. Although this was a retrospective study, all patients signed an informed consent form.

\section{Statistical analysis}

Categorical variables were compared statistically using the $\chi^{2}$ test, whereas continuous parameters were compared using the two-tailed Student's $t$-test. A value of $P<0.05$ was considered statistically significant.

The Primer of Biostatistics (statistical software) was used for the statistical analysis.

\section{Results}

The age of the 271 patients ranged between 20 and 73 years, with an average ( \pm standard deviation [SD]) of 51.6 years ( \pm 11.9 years $)$.

The clinical characteristics of the study patients were summarized in Table 1. As shown in the table, the number of younger patients aged less than 40 years was 46 , accounting for $16.9 \%$ of the whole sample. The age of the younger patients ranged from 20 to 39 years, with a mean $( \pm S D)$ age of 31.6 years ( \pm 4.8 years), and disease onset was on average 10.08 months ( \pm 1.44 months) prior. The patients aged over 40 years numbered 225 (83.02\% of all the cases). The age of the older patients ranged from 40 to 73 years, with a mean age of 55.7 years ( \pm 8.3 years), and their disease onset was on average 10.06 months ( \pm 2.02 months) prior.

Sonographic observation of the average volume of penile plaque was also different in the two age groups. In patients aged $<40$ years, the average volume of plaque was $0.789 \mathrm{~cm}^{3}$, while in patients aged $\geq 40$ years, it was $0.520 \mathrm{~cm}^{3}(P=0.003)$. 
Table I Clinical characteristics of PD patients in the two groups

\begin{tabular}{|c|c|c|c|}
\hline Characteristics & $\begin{array}{l}\text { Younger PD } \\
\text { patients } \\
\text { ( }<40 \text { years) } \\
\text { group A }\end{array}$ & $\begin{array}{l}\text { Older PD } \\
\text { patients } \\
\text { ( } \geq 40 \text { years) } \\
\text { group B }\end{array}$ & $\begin{array}{l}\text { Statistical } \\
\text { analysis } \\
\text { P-value } \\
\text { A versus B }\end{array}$ \\
\hline PD patients, n (\%) & $46(16.97 \%)$ & 225 (83.02\%) & - \\
\hline Age (years) & $31.67 \pm 4.86$ & $55.74 \pm 8.32$ & $\begin{array}{l}P<0.0001 \\
(t \text {-test })\end{array}$ \\
\hline $\begin{array}{l}\text { Time since PD onset } \\
\text { (months) }\end{array}$ & $10.08 \pm 1.44$ & $10.06 \pm 2.02$ & $\begin{array}{l}P=0.939 \\
(t \text {-test })\end{array}$ \\
\hline Plaque volume $\left(\mathrm{cm}^{3}\right)$ & $0.789 \pm 0.876$ & $0.520 \pm 0.472$ & $\begin{array}{l}P=0.0033 \\
(t \text {-test })\end{array}$ \\
\hline $\begin{array}{l}\text { Objective penile } \\
\text { curvature, n (\%) }\end{array}$ & 40 (86.9\%) & I 78 (79.1\%) & $\begin{array}{l}P=0.307 \\
\left(\chi^{2} \text { test }\right)\end{array}$ \\
\hline Curvature $\left({ }^{\circ}\right)$ & $30.55 \pm|2.7|$ & $25.61 \pm 12.46$ & $\begin{array}{l}P=0.0252 \\
(t \text {-test })\end{array}$ \\
\hline $\begin{array}{l}\text { Associated penile pain } \\
\text { during erection, } n(\%)\end{array}$ & $36(78.26 \%)$ & 140 (62.22\%) & $\begin{array}{l}P=0.042 \\
\left(\chi^{2} \text { test }\right)\end{array}$ \\
\hline $\begin{array}{l}\text { VAS score of PD } \\
\text { patients with penile } \\
\text { pain }\end{array}$ & $5.25 \pm 1.18$ & $3.83 \pm 2.05$ & $\begin{array}{l}P=0.000 I \\
(t \text {-test })\end{array}$ \\
\hline Associated ED, n (\%) & $15(32.6 \%)$ & 83 (36.8\%) & $\begin{array}{l}P=0.617 \\
\left(\chi^{2} \text { test }\right)\end{array}$ \\
\hline $\begin{array}{l}\text { Erectile function index } \\
\text { of PD patients with ED }\end{array}$ & $20.133 \pm 3.398$ & $20.156 \pm 4.004$ & $\begin{array}{l}P=0.983 \\
(t \text {-test })\end{array}$ \\
\hline
\end{tabular}

Note: Values were expressed as mean \pm SD, unless otherwise stated. Abbreviations: ED, erectile dysfunction; PD, Peyronie's disease; SD, standard deviation; VAS, visual analog scale.

A similar difference was detected with respect to angle of curvature and intensity of pain. In patients aged $<40$ years, the average angle of curvature was $30.5^{\circ}$, while in patients aged $\geq 40$ years, the average angle was $25.61^{\circ}(P=0.025)$.

In patients aged $<40$ years, the mean pain score (VAS score) was 5.2 , while in patients aged $\geq 40$ years, the average score was $3.8(P=0.0001)$.

There were no statistically significant differences with regard to the presence of erectile dysfunction or its IIEF score in the two age groups.

Diabetes was noted in 2.1\% (1/46) of the patients under the age of 40 years and in $12.4 \%$ (28/225) of the patients aged $\geq 40$ years $(P=0.0375)$.

\section{Discussion}

In the scientific literature, the prevalence of $\mathrm{PD}$ at a young age ( $<40$ years) is indicated to vary between $1.5 \%$ and $10.8 \% .^{22-25}$ Our retrospective study shows a significantly higher prevalence of PD in young patients (16.97\%). It must be noted that the previous studies are outdated, as the most recent of these dates back to 8 years ago, ${ }^{25}$ and one can go as far back as references to case histories collected between 1950 and $1984 .{ }^{22}$ We think that in addition to differences in demographic and social contexts, our study was carried out at a time of better understanding and information on PD. Until a few years ago, for example, there was no forum - either in Italy or abroad - dedicated to patients with this disease, and it is now known that younger people resort more often to the media, particularly the Internet, for any type of information, including medical information. A survey carried out by CENSIS Italian Foundation (Center for Social Studies and Policies) in 2014 revealed that young people (aged 14-44 years) use news websites much more than do people over the age of $44 .^{32}$ So we hypothesize that the more frequent search for information carried out by the younger population may provide a greater chance of diagnosis for younger patients, resulting in a higher incidence of patients with PD in the lower age groups. Besides this, the results of our study showed significant differences between the two age groups. At an equal distance of time from the beginning of the disease, the average penile plaque (zone of $\mathrm{PD}$ ) was significantly greater in the group of younger patients $(P=0.003)$. This increased progression of $\mathrm{PD}$ and its more acute debut in younger patients has already been confirmed in the studies by other authors. ${ }^{22-24}$ Likewise, the appearance and progression of penile curvature were higher in younger patients: the average angle of penile curvature and the average score of penile pain intensity in young men were significantly higher than in patients $\geq 40$ years $(P=0.025$ and $P=0.0001$, respectively). In the younger patients, pain was more intense (VAS $=5.2$ versus 3.8) and was also more frequently present than in patients aged $\geq 40$ years $(78.2 \%$ versus $62.2 \%)(P=0.042)$. In our study, differences with regard to the presence of erectile dysfunction and to IIEF score in the two age groups were not statistically significant; in our opinion, this is a result of the natural higher prevalence of ED in older patients.

In contrast to findings of other authors, ${ }^{25}$ diabetes was noted in $2.1 \%(1 / 46)$ of the patients under the age of 40 years.

\section{Conclusion}

Our study shows a significant increase in the prevalence of PD in the younger population, and this update adds to our current understanding of the pathophysiological characteristics of the disease.

Our results show a $16.9 \%$ prevalence of $\mathrm{PD}$, which is higher than in older studies. Further important points that have emerged from our study concern the younger patients with PD (age $<40$ years): in these patients, the disease progressed faster, and penile nodules tended to increase more in size over the same time span. The same was true 
for the level of penile curvature and the intensity of pain, which were greater than in patients aged $\geq 40$ years. Since several studies on the "natural history" of PD have confirmed a high percentage of worsening and low rates of spontaneous resolution, ${ }^{28,33-35}$ we may conclude that as PD in young patients has a more acute onset and a greater possibility of progression, it should be treated conservatively as soon as it is diagnosed.

\section{Disclosure}

The authors report no conflicts of interest in this work.

\section{References}

1. Gonzalez-Cadavid NF. Mechanisms of penile fibrosis. J Sex Med. 2009;6(Suppl 3):S353-S362.

2. Paulis G, Brancato T. Inflammatory mechanisms and oxidative stress in Peyronie's disease: therapeutic "rationale" and related emerging treatment strategies. Inflamm Allergy Drug Targets. 2012;11(1):48-57.

3. El-Sakka AI, Hassoba HM, Pillarisetty RJ, Dahiya R, Lue TF. Peyronie's disease is associated with an increase in transforming growth factor-beta protein expression. J Urol. 1997;158(4):1391-1394.

4. Zimmermann RP, Feil G, Bock C, Hoeltl L, Stenzl A. Significant alterations of serum cytokine levels in patients with Peyronie's disease. Int Braz J Urol. 2008;34(4):457-466; discussion 466.

5. Devine CJ Jr, Somers KD, Jordan GH, Schlossberg SM. Proposal: trauma as the cause of the Peyronie's lesion. J Urol. 1997;157(1):285-290.

6. Jarow JP, Lowe FC. Penile trauma: an etiologic factor in Peyronie's disease and erectile dysfunction. $J$ Urol. 1997;158(4):1388-1390.

7. Zargooshi J. Trauma as the cause of Peyronie's disease: penile fracture as a model of trauma. J Urol. 2004;172(1):186-188.

8. Diegelmann RF. Cellular and biochemical aspects of normal and abnormal wound healing: an overview. J Urol. 1997;157(1):298-302.

9. Somers KD, Dawson DM. Fibrin deposition in Peyronie's disease plaque. J Urol. 1997;157(1):311-315.

10. Van de Water L. Mechanisms by which fibrin and fibronectin appear in healing wounds: implications for Peyronie's disease. J Urol. 1997; 157(1):306-310.

11. Schiavino D, Sasso F, Nucera E, et al. Immunologic findings in Peyronie's disease: a controlled study. Urology. 1997;50(5):764-768.

12. Stewart S, Malto M, Sandberg L, Colburn KK. Increased serum levels of anti-elastin antibodies in patients with Peyronie's disease. J Urol. 1994;152(1):105-106.

13. Ventimiglia E, Capogrosso P, Colicchia M, et al. Peyronie's disease and autoimmunity-a real-life clinical study and comprehensive review. J Sex Med. 2015;12(4):1062-1069.

14. Chilton CP, Castle WM, Westwood CA, Pryor JP. Factors associated in the aetiology of peyronie's disease. Br J Urol. 1982;54(6):748-750.

15. Nugteren HM, Nijman JM, de Jong IJ, van Driel MF. The association between Peyronie's and Dupuytren's disease. Int J Impot Res. 2011; 23(4):142-145.

16. Lyles KW, Gold DT, Newton RA, et al. Peyronie's disease is associated with Paget's disease of bone. J Bone Miner Res. 1997;12(6):929-934.
17. Dolmans GH, Werker PM, de Jong IJ, Nijman RJ, Wijmenga C, Ophoff RA; LifeLines Cohort Study. WNT2 locus is involved in genetic susceptibility of Peyronie's disease. J Sex Med. 2012;9(5):1430-1434.

18. Schwarzer U, Sommer F, Klotz T, Braun M, Reifenrath B, Engelmann U. The prevalence of Peyronie's disease: results of a large survey. $B J U$ Int. 2001;88(7):727-730.

19. Mulhall JP, Creech SD, Boorjian SA, et al. Subjective and objective analysis of the prevalence of Peyronie's disease in a population of men presenting for prostate cancer screening. J Urol. 2004;171(6 Pt 1): 2350-2353.

20. Dibenedetti DB, Nguyen D, Zografos L, Ziemiecki R, Zhou X. A population-based study of Peyronie's disease: Prevalence and treatment patterns in the United States. Adv Urol. 2011;2011:282503.

21. Tal R, Hall MS, Alex B, Choi J, Mulhall JP. Peyronie's disease in teenagers. J Sex Med. 2012;9(1):302-308.

22. Lindsay MB, Schain DM, Grambsch P, Benson RC, Beard CM, Kurland LT. The incidence of Peyronie's disease in Rochester, Minnesota, 1950 through 1984. J Urol. 1991;146(4):1007-1009.

23. Tefekli A, Kandirali E, Erol H, Alp T, Köksal T, Kadioğlu A. Peyronie's disease in men under age 40: characteristics and outcome. Int J Impot Res. 2001;13(1):18-23.

24. Levine LA, Estrada CR, Storm DW, Matkov TG. Peyronie disease in younger men: characteristics and treatment results. J Androl. 2003; 24(1):27-32.

25. Deveci S, Hopps CV, O'Brien K, Parker M, Guhring P, Mulhall JP. Defining the clinical characteristics of Peyronie's disease in young men. J Sex Med. 2007;4(2):485-490.

26. Behre HM, Zitzmann M. Imaging diagnostics. In: Nieschlag E, Behre HM, Nieschlag S, editors. Andrology: Male Reproductive Health and Dysfunction. Berlin: Springer-Verlag; 2010:101-108.

27. Kim CK, Cho JY. Prostate. In: Kim SH, editor. Radiology Illustrated: Uroradiology. Berlin: Springer-Verlag; 2012:826.

28. Paulis G, Cavallini G. Clinical evaluation of natural history of Peyronie's disease: our experience, old myths and new certainties. Inflamm Allergy Drug Targets. 2013;12(5):341-348.

29. Kelâmi A. Autophotography in evaluation of functional penile disorders. Urology. 1983;21(6):628-629.

30. Farrar JT, Young JP, LaMoreaux L, Werth JL, Poole RM. Clinical importance of changes in chronic pain intensity measured on an 11-point numerical pain rating scale. Pain. 2001;94(2):149-158.

31. Rosen RC, Riley A, Wagner G, Osterloh IH, Kirkpatrick J, Mishra A. The international index of erectile function (IIEF): a multidimensional scale for assessment of erectile dysfunction. Urology. 1997;49(6):822-830.

32. CENSIS. Rapporto Sulla Situazione Sociale del Paese 2014 [Report on the Social Situation of the Country 2014]. Rome: CENSIS; 2014. Available from: http://www.ipasvi.it/archivio_news/attualita/1375/SINTESI\%20RAPPORTO\%20CENSIS\%202014.pdf. Accessed May 24, 2015. Italian.

33. Kadioglu A, Tefekli A, Erol B, Oktar T, Tunc M, Tellaloglu S. A retrospective review of 307 men with Peyronie's disease. J Urol. 2002;168(3):1075-1079.

34. Mulhall JP, Schiff J, Guhring P. An analysis of the natural history of Peyronie's disease. J Urol. 2006;175(6):2115-2118; discussion 2118.

35. Bekos A, Arvaniti M, Hatzimouratidis K, Moysidis K, Tzortzis V, Hatzichristou D. The natural history of Peyronie's disease: an ultrasonography-based study. Eur Urol. 2008;53(3):644-650. 
Research and Reports in Urology

\section{Publish your work in this journal}

Research and Reports in Urology is an international, peer-reviewed, open access journal publishing original research, reports, editorials, reviews and commentaries on all aspects of adult and pediatric urology in the clinic and laboratory including the following topics: Pathology, pathophysiology of urological disease; Investigation and treatment of

urological disease; Pharmacology of drugs used for the treatment of urological disease. The manuscript management system is completely online and includes a very quick and fair peer-review system, which is all easy to use. Visit http://www.dovepress.com/testimonials.php to read real quotes from published authors.

Submit your manuscript here: http://www.dovepress.com/research-and-reports-in-urology-journal 